\title{
Fair Value Accounting - Fact Or Fancy?
}

\author{
Andrew Wagner, California State University, Stanislaus, USA
}

Don Garner, California State University, Stanislaus, USA

\begin{abstract}
Accounting methods had used historical costs prior to FAS 115 and FAS 157. For financial intermediaries in particular, fair value accounting (FVA) has replaced verifiable historical costs with market valuations that, for illiquid assets, rely on assumptions and are not a priori verifiable. The effect of using these relatively new financial accounting standards has been to convert the valuation basis from historical costs accounting to fair value accounting. The recent literature seems to indicate that the current guideline about fair value accounting may be appropriate in certain cases; but in many cases, it does not appear so. Nevertheless, the Financial Accounting Standards Board (FASB) and the Securities and Exchange Commission (SEC) are, apparently, maintaining their current directives for accounting valuation. The Enron case clearly showed that FVA aided the firm in misstating income statements and balance sheets. Given the accounting literature on the subject, the use of FVA also appears to have contributed to the liquidity crisis of 2008 in a negative way in that (1) the use of FVA combined with mandatory capital adequacy requirement introduced a negative feedback mechanism which caused asset prices to fall more than they otherwise would have, and (2) the use of FVA seems to have caused a lack of confidence in valuations reported on banks' financial reports. This paper will examine the problems inherent in the replacement of historical cost accounting with fair value accounting, with particular focus on the veracity and verifiability of FVA numbers. Our result indicates that accounting methods cannot possibly be responsible for various valuation models, particularly with respect to certain derivative contracts, such as energy swaps and credit default swaps which cannot be replicated in practice.
\end{abstract}

Keywords: fair value accounting, capital requirements, positive feedback mechanism

\section{INTRODUCTION}

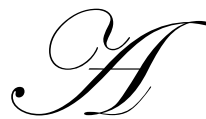

ccounting methods had used historical costs prior to FAS 115 (1993) and FAS 157 (2007). For financial intermediaries in particular, fair value accounting (FVA) has replaced verifiable historical costs with market valuations that, for illiquid assets, rely on assumptions and are not a priori verifiable. The effect of using these relatively new financial accounting standards has been to convert the valuation basis from historical costs accounting to fair value accounting, also called "mark-to-market" accounting.

Mark-to-market, or fair value accounting, refers to the accounting standard of assigning a value to a position held in a financial instrument based on the current fair market price for the instrument or similar instruments. Fair value accounting (FVA) has been a part of US Generally Accepted Accounting Principles (GAAP) since the 1990s. Mark-to-market is a measure of the fair value of accounts (e.g., assets and liabilities) that can change over time. It is the act of recording the price or value of a security, portfolio or account to reflect its current market value rather than its book value. For example, mutual funds are marked to market on a daily basis at the market close so that investors have an idea of the fund's net asset value (NAV). FAS 115 and FAS 157 dictate the current guidelines for FVA. The standard has been used by companies, like Enron, in manipulative ways to achieve spurious valuations, resulting in new restrictive regulations (e.g., Sarbanes-Oxley.)

The practice of marking to market originated in the futures exchanges. In these exchanges, a settlement price is established at the end of the trading day at which all participants settle, realizing any gains or losses on their contracts that have accrued during the day. Some of the less liquid derivatives are also marked to market, but their prices are established not by market trading or any other objectively determined or readily available price, but rather 
by algorithms - computer programs that compute values based on data input from other, more active markets. For example, OTC options could be marked to market using the Black-Scholes Option Pricing Model or a variant of BSOPM. FVA works in the same way, using various valuation models to state the value of illiquid assets on financial statements.

There are three levels of FVA:

1. Level 1: Statement values are quoted prices in active markets for identical assets or liabilities.

2. Level 2: Statement values are derived from valuation models using observable inputs, such as the discount rate on similar assets.

3. Level 3: Statement values are derived from valuation models using unobservable inputs. They are used when there is no market for the asset or liability.

What happens when formerly liquid securities abruptly become illiquid and are no longer being traded, as happened, for example, with collateralized debt obligations (CDOs) in the latter half of 2008? Do we just value these securities at zero? The securities in question will have positive payoffs in the future, so their value cannot be zero even though no buyers are available. The FAS 157 rule has often been criticized as 'mark to make-believe.' In the absence of market information (when the market 'dries up'), an entity is allowed to use its own assumptions about what the price would be if a willing buyer actually existed. The alternative, using market values to record the values of assets whose market has suddenly become illiquid, is to value such assets at zero.

It has been argued in the accounting and economics literature that the market for collateralized debt obligations (CDOs) would not have become illiquid, at least not as quickly as it did, if not for FVA. I argue here that it was FVA in concert with capital adequacy requirements (Basel I and Basel II) that created a positive feedback loop which contributed to the panic selling and resultant market illiquidity of the 2008 financial market crisis.

\section{POSITIVE FEEDBACK AND SYSTEM STABILITY}

In complex systems, there are typically many feedback mechanisms. Some of them are positive and some of them are negative. A positive feedback mechanism amplifies; it creates additional oscillation. A negative feedback mechanism reduces amplification, which is helpful for system stability and self-correction. An equilibrium exists when negative feedback mechanisms outweigh the effects of the positive feedback mechanisms. When combined with capital adequacy requirements, FVA contributes to excessive leverage in boom periods and to excessive write-downs in busts. This is an example of positive feedback. The adaptation of FVA, in combination with pre-existing but evolving capital adequacy requirements (Basel I and Basel II), created a destabilizing positive feedback mechanism without an offsetting negative feedback mechanism. When the real estate asset bubble deflated, this negative feedback mechanism both accelerated the market crash and amplified its effect.

As assets increase in market value during boom periods, banks can and do increase debt levels while still keeping leverage ratios within capital adequacy requirements. As long as the net interest margin is positive, increasing the level of debt increases net worth. By the same token, FVA, combined, with capital adequacy requirements, leads to write-downs during market bust periods. As assets decrease in value, banks are forced to write-down or sell certain assets, such as CDOs, in order to meet compulsory capital adequacy requirements. This can and did lead to contagion as prices from asset devaluation became relevant for other banks. As banks write off certain assets, those assets' prices decline further. Hence, such write-downs deplete bank capital as other banks mark to market their assets, causing further write-downs, setting off a downward spiral as banks are eventually forced to sell assets at "fire sale" prices. The cycle continues until a buyer can no longer be found for the assets in question.

\section{COUNTER-ARGUMENTS}

Much of the recent accounting empirical literature concludes that (FVA) contributed to the recent credit crisis, while defenders of FVA assert that the problem is not with the reporting standards themselves, but with the economic situation, and that the FVA standard actually helped alleviate the crisis in that it caused the economic phenomena to be reported as it happened so that it could be dealt with sooner than otherwise. However, the 
immediate reaction to the crisis in 2008 was to halt the panic selling that occurred by buying troubled assets, soon followed by injecting capital directly into the troubled firms through the purchase of equity shares. If the crash in asset prices had occurred more slowly, this 'fix' would likely have been less painful to current and future taxpayers. If the illiquidity problem hadn't been so urgent, then perhaps the government ownership of private equities for the first time in history could have been avoided altogether.

One could also argue that banks were highly levered during the housing boom and relied heavily on collateralized repurchase agreements, where the amount of debt that can be obtained depends on the market value of the assets used as collateral, regardless of accounting convention. Investors would have been concerned about banks with substantial (subprime) mortgage exposure once the problems in the mortgage market were apparent, even if banks had not written down mortgage-related assets and simply reported their historical cost. Thus, investment funds, investment banks or bank holding companies that relied heavily on short-term borrowing and had substantial subprime exposures would have faced major difficulties, regardless. However, given capital adequacy requirements, it is doubtful that mortgage-related assets would have fallen in market value by as much as they did if FVA had not been used in calculating leverage ratios. After all, the market price of CDOs in September of 2008 effectively fell to zero despite the fact that the majority of mortgages were not at risk of default.

Empirical studies in the accounting literature indicate that the extent of fair value reporting is associated with an increase in contagion among banks. The increase in bank contagion is most severe during periods of market illiquidity. Cross-sectional analyses suggest that increased bank contagion associated with fair value accounting is more likely to spread to banks that are less capitalized or have a relatively higher proportion of fair value assets and liabilities.

\section{FAIR VALUE ACCOUNTING AND THE PURPOSE OF FINANCIAL REPORTING}

The purpose of financial reporting must be taken into account in determining whether a measurement meets that objective. The financial statements should accurately reflect the financial position of the firm at the time the statement is produced.

What is the objective of FVA? The primary objective seems to be "decision usefulness." For example, an investor who is interested in buying or selling securities would want to know, "Are financial statements consistent in showing what a company is worth?" FVA is intended to represent value rather than historical cash flows and so, presumably, would be preferable to the investor who is primarily concerned with this question. However, the investor is also concerned with risk and transparency and is therefore looking for financial statements with verifiable numbers. This is not a problem with level 1 FVA because everyone agrees on what the price of a given security was at a given time if that security had a quoted price in an active market at that time, but for levels 2 and 3, FVA the numbers are not verifiable. For the financial statement to be useful to those using it to make business and investment decisions, the financial position of the firm must be verifiably disclosed with accuracy. Particularly with levels 2 and 3 FVA, the use of mark to market accounting, instead of historical cost accounting, relies on assumed inputs to pricing models (such as prevailing discount rates for similar securities) and has placed emphasis on future cash flows, while considerably less emphasis has been placed on the reliability and integrity of information.

It has been well established that in using historical costs, we can still arrive at accurate firm valuation. ${ }^{1}$ Moreover, using FVA overlooks an important function of the balance sheet. That is, as a record of cumulative, historical transactions. It is from this history of interaction with markets that valuations had been made prior to the widespread use of FVA.

What FVA did, in effect, was to take focus away from objective and verifiable historical costs. Without any hindsight knowledge, attempting to estimate a fair market value in the absence of a willing buyer is, by definition, unverifiable. No amount of fine-tuning in any valuation model could possibly allow the accountant to verify a priori fair value balances.

\footnotetext{
${ }^{1}$ See for example Penman, 2006, "Financial Reporting Quality: Is Fair Value a Plus or a Minus?"
} 
The SEC seems to agree that there are problems with FVA. In 2009, the SEC released a report on its valuation guidelines per Congressional mandate. While the report recommended that the SEC maintain its current fair value accounting standards, it acknowledged that there may be different account standards for certain assets in certain situations. Specifically, the report states that the SEC is "reconsidering the accounting for impairments and the development of additional guidance for determining fair value of investments in inactive markets, including situations where market prices are not readily available."

\section{CONCLUSIONS}

We argue here that the illiquidity problems that arose after the adoption of fair value accounting standards were not due to the accounting standards themselves, but rather from the interaction between FVA standards and preexisting capital adequacy requirements. The two directives taken together, without an offsetting change in regulatory structure, impose a positive feedback effect that destabilizes the financial system, increasing systemic risk. Ironically, the primary rationale for capital adequacy requirements is the containment of systemic risk. ${ }^{2}$ At this time, the FASB, which set the FVA standards, and the bank regulators who set capital adequacy requirements, do not coordinate with each other. However, if FVA and capital requirements are going to continue to act in concert to force asset sales, then a coordinated reaction from FASB and bank regulators would be prudent.

\section{AUTHOR INFORMATION}

Don E. Garner, Ph.D., CPA, CIA is professor and former chair of the Department of Accounting in the College of Business Administration at California State University, Stanislaus, where he specializes in the area of auditing and accounting. He is a certified public accountant and a certified internal auditor. He has coauthored a number of monographs on the practice of accounting internationally and in specific locales including the Pacific Basic and the Islamic Middle East.

Andrew J. Wagner is professor of finance and program director of the Master of Science in Business Administration (MSBA) program at California State University, Stanislaus. He specializes in the areas of international finance and derivative securities. Originally from Philadelphia, Pennsylvania, Andrew received his $\mathrm{Ph} . \mathrm{D}$. from Texas A\&M University. Andrew is married and has three beautiful daughters.

\section{REFERENCES}

1. Allen, F. and E. Carletti, 2008, "The Role of Liquidity in Financial Crises," available at SSRN: http://ssrn.com/abstract=1268367.

2. $\quad$ Fisher, Richard W., "Financial Reform or Financial Dementia?" Remarks at the SW Graduate School of Banking 53rd Annual Keynote Address and Banquet, Dallas, Texas, June 3, 2010.

3. Goh, W.B., J. Ng and K. O. Yong, 2009, "Market Pricing of Banks' Fair Value Assets Reported under SFAS 157 during the 2008 Economic Crisis," available at SSRN: http://ssrn.com/abstract=1335848.

4. Khan, Urooj, 2009, "Does Fair Value Accounting Contribute to Systemic Risk in the Banking Industry?" available at SSRN: http://ssrn.com/abstract=1327596.

5. Magnan, M. and Cormier, D., 2005, From Accounting to "Forecounting". Accounting Perspectives 4(2), 243-257.

6. Magnan, Michel, 2009, "Fair Value Accounting and the Financial Crisis: Messenger or Contributor?" CIRANO - Scientific Publications Paper No. 2009s-27, available at SSRN: http://ssrn.com/abstract=1504128.

7. Martin, R.D., J.S. Rich, and T.J. Wilks, 2006, “Auditing Fair Value Measurements: A Synthesis of Relevant Research.” Accounting Horizons 20 (3), 287.

8. Penman, 2006, "Financial Reporting Quality: Is Fair Value a Plus or a Minus?" presented at the Information for Better Markets Conference Institute of Chartered Accountants in England and Wales.

9. Plantin, G., H. Sapra and H.S. Shin, 2008, “Marking-to-market: Panacea or Pandora's Box?” Journal of Accounting Research, 46 (2), 435-460, available at SSRN: http://ssrn.com/abstract=1186362.

10. Watts, R. And K. Ramanna. 2007. Evidence on the Effects of Unverifiable Fair-Value Accounting. Harvard Business School Working Paper 08-014 (http://ssrn.com/abstract 1012139)

${ }^{2}$ Richard W. Fisher, "Financial Reform or Financial Dementia?" 